\title{
Dry Bean Sensitivity to Group 15 Herbicides Applied Preemergence
}

\author{
Nader Soltani, Christy Shropshire, Peter H. Sikkema \\ University of Guelph, Ridgetown Campus, Ridgetown, Canada \\ Email:soltanin@uoguelph.ca
}

How to cite this paper: Soltani, N., Shropshire, C. and Sikkema, P.H. (2018) Dry Bean Sensitivity to Group 15 Herbicides Applied Preemergence. American Journal of Plant Sciences, 9, 1414-1423.

https://doi.org/10.4236/ajps.2018.97103

Received: May 8, 2018

Accepted: June 12, 2018

Published: June 15, 2018

Copyright $\odot 2018$ by authors and Scientific Research Publishing Inc. This work is licensed under the Creative Commons Attribution International License (CC BY 4.0).

http://creativecommons.org/licenses/by/4.0/

\begin{abstract}
Field experiments (4 in total) were conducted in 2016 and 2017 in southwestern Ontario to compare the sensitivity of dry bean to four Group 15 herbicides applied preemergence (PRE). At 4 weeks after emergence (WAE), pethoxamid, $S$-metolachlor, dimethenamid- $P$ and pyroxasulfone applied PRE at the $2 \mathrm{X}$ rate caused $5 \%, 9 \%, 9 \%$ and $14 \%$ visible injury in adzuki bean, $2 \%, 2 \%$, $2 \%$ and $3 \%$ visible injury in kidney bean, $6 \%, 4 \%, 5 \%$ and $4 \%$ visible injury in small red Mexican (SRM) bean, and 9\%,6\%,8\% and 9\% visible injury in white bean, respectively. Pyroxasulfone reduced adzuki bean shoot biomass ( $\mathrm{m}^{-1}$ row) $42 \%$ and height $12 \%$. However, the other Group 15 herbicides did not reduce shoot biomass and height of adzuki bean. Kidney bean shoot biomass and height were not adversely affected by the Group 15 herbicides evaluated. $S$-metolachlor caused no adverse effect on SRM bean dry weight or height, but pethoxamid, dimethenamid- $P$ and pyroxasulfone at the $2 \mathrm{X}$ rate reduced dry weight $26 \%, 28 \%$ and $28 \%$ and height $7 \%, 7 \%$ and $7 \%$ in SRM bean, respectively. Pethoxamid, $S$-metolachlor, dimethenamid- $P$, and pyroxasulfone applied PRE at the $2 \mathrm{X}$ rate reduced white bean dry weight $50 \%, 37 \%$, $47 \%$ and $43 \%$ and height $16 \%, 10 \%, 16 \%$ and $15 \%$ in white bean, respectively. Pyroxasulfone (2X rate), applied PRE, reduced bean stand count and seed yield $12 \%$ and $7 \%$, respectively. However, pethoxamid, $S$-metolachlor, and dimethenamid- $P$, applied PRE caused no decrease in stand count and seed yield of dry beans evaluated. In general, kidney and SRM bean are most tolerant, white bean is intermediate, and adzuki bean is most sensitive to Group 15 herbicides applied PRE.
\end{abstract}

\section{Keywords}

Adzuki Bean, Dimethenamid- $P$, Kidney Bean, Pethoxamid, Pyroxasulfone, Small Red Mexican Bean, $S$-Metolachlor, White Bean 


\section{Introduction}

Dry bean is a valuable niche market crop grown in Canada. Most of the dry bean produced in Canada is grown in Ontario and Manitoba. During 2007 to 2016, on average growers in Ontario harvested 48,455 hectares and produced 107,000 tonnes of dry bean annually, valued at US $\$ 78$ million while growers in Manitoba harvested 44,608 hectares and produced 83,000 tonnes of dry bean annually, valued at US\$61 million [1]. Controlling weeds is important to minimize yield loss due to weed interference and maximize dry yield and profitability. Growers in Ontario can lose as much as $1232 \mathrm{~kg} \cdot \mathrm{ha}^{-1}$ or $56 \%$ of their dry bean yield valued at US $\$ 44$ million if weeds are not controlled [1].

Group 15 herbicides include acetamide, chloroacetamide, oxyacetamide, and tetrazolinone chemical families and control susceptible weeds by impairing the formation of fatty acid biosynthesis [2]. Active ingredients within these classes of herbicides include pethoxamid, $S$-metolachlor, dimethenamid- $P$, and pyroxasulfone which have potential to effectively control common annual grass and broadleaf weeds in dry bean [2] [3] [4]. Group 15 herbicides do not affect seed germination, but control or suppress seedling weeds prior to emergence [5]. Pethoxamid, $S$-metolachlor, dimethenamid- $P$, and pyroxasulfone can provide control of annual grass weeds such as barnyardgrass [Echinochloa crus-galli (P.) Beauv.], witchgrass (Panicum spp.), foxtails (Setaria spp.) and crabgrass (Digitaria spp.) as well as some small-seeded broadleaf weeds including Amaranthus, Solanum, Chenopodium, and Ambrosia species [2] [3] [4] [5]. Group 15 herbicides are primarily absorbed by emerging shoots of susceptible annual grass seedlings and prevent shoot formation through interrupting the growth of the apical meristem and coleoptiles after seed germination [4] [5].

Response of dry bean market classes has not been collectively compared for sensitivity to the Group 15 herbicides including pethoxamid, $S$-metolachlor, dimethenamid- $P$, and pyroxasulfone applied preemergence (PRE) under Ontario environmental conditions. Dry beans have been shown to respond differently to soil-applied herbicides [6] [7] [8] [9] [10].

The objective of this study was to compare the tolerance of four commonly grown market classes of dry bean in Ontario to pethoxamid at 1200 and $2400 \mathrm{~g}$ ai ha ${ }^{-1}, S$-metolachlor at 1600 and $3200 \mathrm{~g}^{\text {ai ha }} \mathrm{ha}^{-1}$, dimethenamid- $P$ at 693 and $1386 \mathrm{~g}$ ai ha $\mathrm{h}^{-1}$, and pyroxasulfone at 100 and $200 \mathrm{~g}^{\text {ai ha }} \mathrm{ha}^{-1}$, applied PRE, representing the proposed registered rate (1X) and twice that rate (2X).

\section{Materials and Methods}

Four field experiments were conducted during 2016 and 2017 at Exeter, Ontario, and Ridgetown, Ontario. The experimental design was a split plot with herbicide treatment (HERB) as the whole plot factor and dry bean type (TYPE) as the split-plot factor with four replicates. The layout was a randomized complete block design for the whole plot portion. Herbicide treatments included pethoxamid at 1200 and $2400 \mathrm{~g}$ ai ha ${ }^{-1}, S$-metolachlor at 1600 and $3200 \mathrm{~g}$ ai ha ${ }^{-1}$, dime- 
thenamid- $P$ at 693 and $1386 \mathrm{~g}$ ai ha ${ }^{-1}$, and pyroxasulfone at 100 and $200 \mathrm{~g}$ ai $\mathrm{ha}^{-1}$. Each plot consisted of eight rows of dry bean [two rows each of adzuki ("Erimo"), kidney ("Red Hawk"), small red Mexican ("Merlot") and white (“T9905”) bean] spaced $0.75 \mathrm{~m}$ apart in rows that were $10 \mathrm{~m}$ long at Exeter and 8 $\mathrm{m}$ long at Ridgetown. Beans were planted approximately $5 \mathrm{~cm}$ deep at a rate of approximately 250,000 seeds $\mathrm{ha}^{-1}$.

Herbicide treatments were applied to the soil surface (not incorporated) 1 - 2 days after planting using a $\mathrm{CO}_{2}$-pressurized backpack sprayer calibrated to deliver $200 \mathrm{~L} \cdot \mathrm{ha}^{-1}$ at $240 \mathrm{kPa}$. The boom was $1.5 \mathrm{~m}$ long with four ultra-low drift ULD120-02 nozzles spaced $0.5 \mathrm{~m}$ apart. All experimental plots were maintained weed-free during the growing season.

Dry bean injury was evaluated visually 1, 2, 4 and 8 weeks after crop emergence (WAE) using a scale of 0 to $100 \%$, with 0 representing no visible injury and $100 \%$ complete plant death respectively. Plant counts, shoot biomass $(1 \mathrm{~m}$ row $^{-1}$ and plant ${ }^{-1}$ ) were measured at $3 \mathrm{WAE}$ and plant height (10 fully extended plants within each plot) was determined at 6 WAE. Dry beans were harvested from each plot with a small plot combine at maturity. Seed yields were adjusted to $14 \%$ seed moisture content for adzuki bean and $18 \%$ seed moisture content for kidney, SRM and white bean.

Data were analyzed using the GLIMMIX procedure in SAS (Ver. 9.4, SAS Institute Inc., Cary, NC) using the Laplace estimation method. The initial model was constructed based on the experimental design, and refined by comparing the most plausible random variable combinations; the final model was selected based on the best fit statistics and studentized residual plots. Fixed effects consisted of herbicide (HERB), dry bean market class (TYPE) and their interaction. Random effects included environment (location-year combinations), the environment by TYPE and environment by HERB by TYPE interactions, replication within environment and its interaction with HERB (whole plot factor). The significance of fixed and random effects was tested using the F-test and likelihood ratio tests, respectively. For each parameter analyzed, different distributions were assessed on the model scale. Once the most appropriate distribution was confirmed, least square means (LSMEANS) were calculated on the data scale using the inverse link function. Tukey's adjustment was applied to pairwise comparisons to determine differences among treatment means at a significance level of 0.05. Percent visible injury was best described using a Poisson distribution and log link; each data point had a value of one added prior to analysis and the final LSMEANS were adjusted by subtracting a value of one. A negative binomial distribution (log link) was used for dry bean biomass per meter of row, and a gamma distribution (log link) was used for dry bean biomass per plant. Plant stand, average plant height, and dry bean yield were analyzed using a Gaussian distribution, while a lognormal distribution provided the best fit for percent moisture at harvest; the default identity link was used in both cases. Differences for main effects (HERB and TYPE) were determined only if the HERB by TYPE 
interaction was negligible; when the interaction was non-negligible, differences among simple effects were determined [11]. For percent visible dry bean injury, the untreated check was assigned a value of zero and was excluded from the analysis because it had zero variance. However, each treatment least square mean was compared independently to the value zero, enabling a comparison between the untreated check and each treatment. LSMEANS for crop moisture were back-transformed for presentation with a correction for log bias [12].

\section{Results and Discussion}

Table 1 provides a summary of the significance of main effects and interaction for dry bean measurements after treatment with four Group 15 herbicides applied PRE. There was a significant dry bean market class by treatment interaction for injury rating at $4 \mathrm{WAE}$, dry weight $\mathrm{m}^{-1}$ of row, dry weight per plant and plant height (Tables 2-4). Results for dry weight $\mathrm{m}^{-1}$ of row and dry weight per plant were similar, therefore only results of dry weight $\mathrm{m}^{-1}$ of row are discussed

Table 1. Significance of main effects and interaction for percent visible injury, stand count, above ground biomass (dry weight) per row and per plant, height, moisture and yield of four dry bean cultivars treated with various preemergence (PRE) Group 15 herbicides at Ridgetown and Exeter, Ontario from 2016 to 2017. Means followed by the same letter within a column are not significantly different according to a Tukey-Kramer multiple range test at $\mathrm{P}<0.05$. Means for a main effect were separated only if the interaction involving the main effect was negligible. ${ }^{a}$

\begin{tabular}{|c|c|c|c|c|c|c|c|c|c|c|c|}
\hline \multicolumn{12}{|c|}{ Visible Injury (\%) } \\
\hline \multicolumn{2}{|l|}{ Main effects ${ }^{\mathrm{b}}$} & \multirow{2}{*}{$\frac{1 \mathrm{WAE}}{}$} & \multirow{2}{*}{$\frac{2 \mathrm{WAE}}{* *}$} & \multirow{2}{*}{$\begin{array}{c}4 \text { WAE } \\
\text { NS }\end{array}$} & \multirow{2}{*}{$\frac{8 \text { WAE }}{* *}$} & \multirow{2}{*}{$\begin{array}{c}\begin{array}{c}\text { Stand } \\
\left(\# \mathrm{~m}^{-1}\right)\end{array} \\
\text { NS }\end{array}$} & \multicolumn{2}{|c|}{$\begin{array}{c}\text { Biomass } \\
\left(\mathrm{g} \cdot \mathrm{m}^{-1}\right) \\
\left(\mathrm{g} \text { plant }{ }^{-1}\right)\end{array}$} & \multirow{2}{*}{$\begin{array}{c}\text { Height } \\
(\mathrm{cm})\end{array}$} & \multirow{2}{*}{$\begin{array}{c}\text { Seed moisture } \\
\text { content } \\
(\%)\end{array}$} & \multirow{2}{*}{$\begin{array}{c}\begin{array}{c}\text { Yield } \\
\left(\mathrm{T} \mathrm{ha}^{-1}\right)\end{array} \\
* *\end{array}$} \\
\hline Dry bean cultivar & & & & & & & $* *$ & $* *$ & & & \\
\hline Adzuki & & $10 \mathrm{c}$ & $11 \mathrm{~b}$ & 6 & $2.5 \mathrm{~b}$ & 17.8 & 10 & 0.6 & 41 & $12.7 \mathrm{a}$ & $2.20 \mathrm{~b}$ \\
\hline Kidney & & $2 \mathrm{a}$ & $3 \mathrm{a}$ & 2 & $0.5 \mathrm{a}$ & 13.2 & 31 & 2.4 & 56 & $16.7 \mathrm{~b}$ & $2.06 \mathrm{~b}$ \\
\hline Small Red Mexican & & $4 \mathrm{ab}$ & $6 \mathrm{ab}$ & 3 & $0.7 \mathrm{a}$ & 16.4 & 32 & 2.0 & 69 & $17.9 \mathrm{~b}$ & $3.32 \mathrm{a}$ \\
\hline White & & $9 \mathrm{bc}$ & $10 \mathrm{~b}$ & 5 & $0.8 \mathrm{a}$ & 16.5 & 20 & 1.3 & 55 & $17.3 \mathrm{~b}$ & $3.40 \mathrm{a}$ \\
\hline Herbicide treatment & Rate $\left(\mathrm{g} \mathrm{ai} \mathrm{ha}^{-1}\right)$ & $* *$ & $* *$ & $* *$ & $* *$ & $* *$ & $* *$ & $* *$ & $* *$ & $* *$ & $* *$ \\
\hline Untreated check & & $0 \mathrm{a}$ & $0 \mathrm{a}$ & 0 & $0.0 \mathrm{a}$ & $16.6 \mathrm{a}$ & 26 & 1.7 & 58 & $15.5 \mathrm{a}$ & $2.80 \mathrm{a}$ \\
\hline Pethoxamid & 1200 & $4 \mathrm{~b}$ & $5 \mathrm{~b}$ & 5 & $0.6 \mathrm{ab}$ & $16.5 \mathrm{a}$ & 23 & 1.4 & 56 & $15.9 \mathrm{ab}$ & $2.81 \mathrm{a}$ \\
\hline Pethoxamid & 2400 & $7 c$ & $9 c$ & 2 & $1.1 \mathrm{bc}$ & $16.2 \mathrm{a}$ & 19 & 1.2 & 54 & $16.6 \mathrm{c}$ & $2.73 \mathrm{ab}$ \\
\hline$S$-metolachlor & 1600 & $4 \mathrm{~b}$ & $5 \mathrm{~b}$ & 5 & $0.7 \mathrm{ab}$ & $16.1 \mathrm{a}$ & 24 & 1.5 & 56 & $15.8 \mathrm{ab}$ & $2.72 \mathrm{ab}$ \\
\hline$S$-metolachlor & 3200 & $7 c$ & $9 c$ & 2 & $1.0 \mathrm{bc}$ & $15.5 \mathrm{ab}$ & 20 & 1.3 & 55 & $16.2 \mathrm{bc}$ & $2.73 \mathrm{ab}$ \\
\hline Dimethenamid- $P$ & 693 & $4 \mathrm{~b}$ & $5 \mathrm{~b}$ & 5 & $0.4 \mathrm{ab}$ & $15.9 \mathrm{ab}$ & 22 & 1.4 & 57 & $15.9 \mathrm{ab}$ & $2.84 \mathrm{a}$ \\
\hline Dimethenamid- $P$ & 1386 & $8 \mathrm{c}$ & $10 \mathrm{c}$ & 2 & $0.9 \mathrm{ab}$ & $15.8 \mathrm{ab}$ & 18 & 1.2 & 53 & $16.4 \mathrm{bc}$ & $2.68 \mathrm{ab}$ \\
\hline Pyroxasulfone & 100 & $4 \mathrm{~b}$ & $4 \mathrm{~b}$ & 6 & $1.1 \mathrm{bc}$ & $16.5 \mathrm{a}$ & 23 & 1.4 & 56 & $15.7 \mathrm{ab}$ & $2.78 \mathrm{ab}$ \\
\hline Pyroxasulfone & 200 & $7 c$ & $9 c$ & 2 & $2.6 \mathrm{c}$ & $14.6 \mathrm{~b}$ & 17 & 1.2 & 53 & $16.2 \mathrm{bc}$ & $2.61 \mathrm{~b}$ \\
\hline \multicolumn{12}{|l|}{ Interaction } \\
\hline $\mathrm{V} \times \mathrm{H}$ & & NS & NS & * & NS & NS & * & $* *$ & $* *$ & NS & NS \\
\hline
\end{tabular}

${ }^{a}$ Abbreviations: $\mathrm{H}$, herbicide treatment; NS, not significant at $\mathrm{P}=0.05$ level; $\mathrm{V}$, dry bean cultivar; WAE, weeks after crop emergence. ${ }^{\mathrm{b}}$ Significance at $\mathrm{P}<0$. 05 and $\mathrm{P}<0.01$ levels denoted by ${ }^{*}$ and ${ }^{* *}$, respectively. 
Table 2. Percent visible injury 4 WAE for four dry bean cultivars treated with various PRE Group 15 herbicides at Ridgetown and Exeter, Ontario from 2016-2017. Means followed by the same letter within a column (a-d) or row (Y-Z) are not significantly different according to a Tukey-Kramer multiple range test at $\mathrm{P}<0.05$. Rows without an uppercase letter have no cultivar differences. ${ }^{\mathrm{a}}$

\begin{tabular}{|c|c|c|c|c|c|c|c|c|c|c|c|c|c|}
\hline \multirow{3}{*}{$\begin{array}{c}\text { Herbicide treatment } \\
\text { Untreated check }\end{array}$} & \multicolumn{13}{|c|}{ Dry bean injury (\%) } \\
\hline & \multirow[t]{2}{*}{$\begin{array}{c}\text { Rate } \\
\left(\mathrm{g} \text { ai ha }{ }^{-1}\right)\end{array}$} & \multicolumn{3}{|c|}{ Adzuki } & \multicolumn{3}{|c|}{ Kidney } & \multicolumn{3}{|c|}{ SRM } & \multicolumn{3}{|c|}{ White } \\
\hline & & 0 & a & & 0 & a & & 0 & a & & 0 & a & \\
\hline Pethoxamid & 1200 & 3 & $\mathrm{~b}$ & & 1 & $\mathrm{~b}$ & & 2 & $\mathrm{bc}$ & & 4 & $\mathrm{~b}$ & \\
\hline Pethoxamid & 2400 & 5 & $\mathrm{bc}$ & $\mathrm{YZ}$ & 2 & $\mathrm{~b}$ & Z & 6 & d & $\mathrm{YZ}$ & 9 & c & $\mathrm{Y}$ \\
\hline$S$-metolachlor & 1600 & 4 & $\mathrm{~b}$ & & 1 & $\mathrm{~b}$ & & 2 & $\mathrm{bc}$ & & 2 & $\mathrm{~b}$ & \\
\hline$S$-metolachlor & 3200 & 9 & $\mathrm{~cd}$ & & 2 & $\mathrm{~b}$ & & 4 & $\mathrm{~cd}$ & & 6 & $\mathrm{bc}$ & \\
\hline Dimethenamid- $P$ & 693 & 4 & $\mathrm{~b}$ & & 1 & $\mathrm{~b}$ & & 2 & $\mathrm{bc}$ & & 3 & $\mathrm{~b}$ & \\
\hline Dimethenamid- $P$ & 1386 & 9 & $\mathrm{~cd}$ & $\mathrm{Y}$ & 2 & $\mathrm{~b}$ & $\mathrm{Z}$ & 5 & d & $\mathrm{YZ}$ & 8 & c & $\mathrm{Y}$ \\
\hline Pyroxasulfone & 100 & 4 & $\mathrm{~b}$ & & 2 & $\mathrm{~b}$ & & 1 & $\mathrm{~b}$ & & 3 & $\mathrm{~b}$ & \\
\hline Pyroxasulfone & 200 & 14 & $\mathrm{~d}$ & $\mathrm{Y}$ & 3 & b & $\mathrm{Z}$ & 4 & $\mathrm{~cd}$ & $\mathrm{YZ}$ & 9 & c & $\mathrm{YZ}$ \\
\hline
\end{tabular}

${ }^{1}$ Abbreviations: PRE, preemergence; SRM, Small Red Mexican; WAE, weeks after crop emergence application.

Table 3. Crop biomass per meter of row 3 WAE for four dry bean cultivars treated with various PRE Group 15 herbicides at Ridgetown and Exeter, Ontario from 2016-2017. Means followed by the same letter within a column (a-d) or row (X-Z) are not significantly different according to a Tukey-Kramer multiple range test at $\mathrm{P}<0.05$. Rows without an uppercase letter have no cultivar differences. ${ }^{a}$

\begin{tabular}{cccccccccc}
\hline & \multicolumn{7}{c}{ Dry bean biomass $\left(\mathrm{g} \cdot \mathrm{m}^{-1}\right)$} \\
\hline Herbicide treatment & $\begin{array}{c}\text { Rate } \\
\left(\mathrm{g} \text { ai ha }{ }^{-1}\right)\end{array}$ & Adzuki & Kidney & SRM & \multicolumn{2}{c}{ White } \\
\hline Untreated check & & 12 & $\mathrm{a}$ & 33 & $\mathrm{a}$ & 39 & $\mathrm{a}$ & 30 & $\mathrm{a}$ \\
Pethoxamid & 1200 & 12 & $\mathrm{a}$ & 31 & $\mathrm{a}$ & 33 & $\mathrm{ab}$ & 22 & $\mathrm{bc}$ \\
Pethoxamid & 2400 & 9 & $\mathrm{ab}$ & 30 & $\mathrm{a}$ & 29 & $\mathrm{~b}$ & 15 & $\mathrm{~d}$ \\
$S$-metolachlor & 1600 & 12 & $\mathrm{a}$ & 31 & $\mathrm{a}$ & 34 & $\mathrm{ab}$ & 23 & $\mathrm{ab}$ \\
$S$-metolachlor & 3200 & 8 & $\mathrm{ab}$ & 33 & $\mathrm{a}$ & 31 & $\mathrm{ab}$ & 19 & $\mathrm{bcd}$ \\
Dimethenamid- $P$ & 693 & 10 & $\mathrm{a}$ & 31 & $\mathrm{a}$ & 31 & $\mathrm{ab}$ & 22 & $\mathrm{bc}$ \\
Dimethenamid- $P$ & 1386 & 9 & $\mathrm{ab}$ & 28 & $\mathrm{a}$ & 28 & $\mathrm{~b}$ & 16 & $\mathrm{~cd}$ \\
Pyroxasulfone & 100 & 11 & $\mathrm{a}$ & 31 & $\mathrm{a}$ & 36 & $\mathrm{ab}$ & 22 & $\mathrm{bc}$ \\
Pyroxasulfone & 200 & 7 & $\mathrm{~b}$ & 28 & $\mathrm{a}$ & 28 & $\mathrm{~b}$ & 17 & $\mathrm{bcd}$ \\
\hline
\end{tabular}

${ }^{a}$ Abbreviations: PRE, preemergence; SRM, Small Red Mexican; WAE, weeks after crop emergence application.

(Table 3). There was no significant dry bean market class by treatment interaction for injury ratings at 1,2 and $8 \mathrm{WAE}$, the plant stand count, moisture and yield (Table 1). 
Table 4. Average height 6 WAE for four dry bean cultivars treated with various PRE Group 15 herbicides at Ridgetown and Exeter, ON from 2016-2017. Means followed by the same letter within a column (a-d) are not significantly different according to a Tukey-Kramer multiple range test at $\mathrm{P}<0.05$. Rows without an uppercase letter have no cultivar differences. ${ }^{a}$

\begin{tabular}{cccccccccc}
\hline & \multicolumn{1}{c}{ Dry bean height $(\mathrm{cm})$} \\
\hline Herbicide treatment $\begin{array}{c}\text { Rate } \\
\left(\mathrm{g} \mathrm{ai} \mathrm{ha}^{-1}\right)\end{array}$ & Adzuki & Kidney & SRM & \multicolumn{2}{c}{ White } \\
\hline Untreated check & & 43 & $\mathrm{a}$ & 57 & $\mathrm{a}$ & 72 & $\mathrm{a}$ & 61 & $\mathrm{a}$ \\
Pethoxamid & 1200 & 42 & $\mathrm{ab}$ & 56 & $\mathrm{a}$ & 70 & $\mathrm{ab}$ & 56 & $\mathrm{abc}$ \\
Pethoxamid & 2400 & 40 & $\mathrm{ab}$ & 56 & $\mathrm{a}$ & 67 & $\mathrm{~b}$ & 51 & $\mathrm{~d}$ \\
$S$-metolachlor & 1600 & 41 & $\mathrm{ab}$ & 55 & $\mathrm{a}$ & 70 & $\mathrm{ab}$ & 56 & $\mathrm{abc}$ \\
$S$-metolachlor & 3200 & 39 & $\mathrm{ab}$ & 56 & $\mathrm{a}$ & 69 & $\mathrm{ab}$ & 55 & $\mathrm{bcd}$ \\
Dimethenamid- $P$ & 693 & 42 & $\mathrm{ab}$ & 57 & $\mathrm{a}$ & 69 & $\mathrm{ab}$ & 58 & $\mathrm{ab}$ \\
Dimethenamid- $P$ & 1386 & 40 & $\mathrm{ab}$ & 56 & $\mathrm{a}$ & 67 & $\mathrm{~b}$ & 51 & $\mathrm{~d}$ \\
Pyroxasulfone & 100 & 42 & $\mathrm{ab}$ & 56 & $\mathrm{a}$ & 68 & $\mathrm{ab}$ & 58 & $\mathrm{ab}$ \\
Pyroxasulfone & 200 & 38 & $\mathrm{~b}$ & 55 & $\mathrm{a}$ & 67 & $\mathrm{~b}$ & 52 & $\mathrm{~cd}$ \\
\hline
\end{tabular}

${ }^{a}$ Abbreviations: PRE, preemergence; SRM, Small Red Mexican; WAE, weeks after crop emergence application.

\subsection{Main Effects of Herbicides}

Group 15 herbicides applied PRE caused as much as 10\%, 2\%, 4\% and 9\% visible injury at $1 \mathrm{WAE}, 11 \%, 3 \%, 6 \%$ and $10 \%$ visible injury at $2 \mathrm{WAE}$, and $2.5 \%, 0.5 \%$, $0.7 \%$ and $0.8 \%$ visible injury at $8 \mathrm{WAE}$ in adzuki, kidney, SRM and white bean, respectively (Table 1 ). Pethoxamid, $S$-metolachlor, dimethenamid- $P$ and pyroxasulfone applied PRE caused as much as 7\%,7\%, $8 \%$ and $7 \%$ visible injury at 1 WAE, $9 \%, 9 \%, 10 \%$ and $9 \%$ visible injury at $2 \mathrm{WAE}$, and $1 \%, 1 \%, 1 \%$ and $3 \%$ visible injury at $8 \mathrm{WAE}$ in dry bean, respectively (Table 1). Pyroxasulfone (200 g ai ha ${ }^{-1}$ ), applied PRE, reduced bean stand count and seed yield $12 \%$ and $7 \%$, respectively. Bean stand count and yield were not adversely affected with pethoxamid, $S$-metolachlor, and dimethenamid- $P$ (Table 1$)$.

\subsection{Adzuki Bean}

At $4 \mathrm{WAE}$, pethoxamid, $S$-metolachlor, dimethenamid- $P$, and pyroxasulfone applied PRE caused 3 to 5, 4 to 9,4 to 9 and $4 \%$ to $14 \%$ visible injury in adzuki bean, respectively (Table 2). Pyroxasulfone applied PRE at $200 \mathrm{~g}$ ai ha ${ }^{-1}$ reduced adzuki bean dry weight ( $\mathrm{m}^{-1}$ row) $42 \%$ and plant height $12 \%$, but did not reduce dry weight $\left(\mathrm{m}^{-1}\right.$ row) or bean height at the $100 \mathrm{~g}^{2}$ ai ha ${ }^{-1}$ rate (Table 3 and Table 4). Adzuki bean dry weight $\mathrm{m}^{-1}$ of row and plant height was also not adversely affected with PRE applied pethoxamid, $S$-metolachlor and dimethenamid- $P$ (Table 3 and Table 4).

Other studies have reported $2 \%$ to $20 \%$ injury and no adverse effect on dry weight and seed yield with pethoxamid applied PRE in adzuki bean [13]. Dimethenamid- $P$ applied PRE has been shown to cause as much as $38 \%$ (Soltani et al. 
2005 ) and $68 \%$ visible adzuki bean injury in adzuki bean [14].

Higher adzuki bean injury seen in this study with pyroxasulfone is similar to other studies. Stewart et al. [15] found 30\% to $61 \%$ visible adzuki bean injury with pyroxasulfone applied PRE at 250 and $500 \mathrm{~g}_{\text {ai ha }}{ }^{-1}$. Similarly, Soltani et al. [16] found $25 \%$ and $55 \%$ visible injury, and $20 \%$ and $30 \%$ seed yield reduction with pyroxasulfone applied PRE at 150 and $300 \mathrm{~g}$ a.i. $\mathrm{ha}^{-1}$ in adzuki bean, respectively. Another study found only $5 \%$ to $22 \%$ visible adzuki bean injury and no yield effects with pyroxasulfone when applied at 100 to $200 \mathrm{~g}$ ai ha ${ }^{-1}$ [17].

\subsection{Kidney Bean}

Pethoxamid, $S$-metolachlor, dimethenamid- $P$, and pyroxasulfone applied PRE caused $3 \%$ or less visible injury at 4 WAE in kidney bean (Table 2). The injury was not significantly different at either rate (1X vs $2 \mathrm{X}$ ) for herbicides evaluated. There was also no decrease in bean dry weight $\mathrm{m}^{-1}$ of row and plant height with pethoxamid, $S$-metolachlor, dimethenamid- $P$, and pyroxasulfone, applied PRE, at rates evaluated (Table 3 and Table 4). Results are similar to other studies that have reported $2 \%$ to $3 \%$ injury with no adverse effect on dry weight and seed yield with pethoxamid applied PRE in kidney bean [13]. Similarly, $S$-metolachlor and dimethenamid- $P$ applied PRE have been reported to cause no adverse effect on dry weight, plant height and seed yield of kidney bean [10] [18]. However, pyroxasulfone applied PRE at 209 and $418 \mathrm{~g}$ a.i. $\mathrm{ha}^{-1}$ has been shown to cause as much as $15 \%$ to $29 \%$ visible injury and reduce dry weight as much as $50 \%$ in kidney bean [16]. In contrast, Taziar et al. [17] found only 3\% and 5\% visible kidney bean injury and no adverse effect on seed yield with pyroxasulfone applied PRE at 100 and $200 \mathrm{~g}_{\text {ai }} \mathrm{ha}^{-1}$, respectively.

\subsection{Small Red Mexican Bean}

At $4 \mathrm{WAE}$, pethoxamid, $S$-metolachlor, dimethenamid- $P$, and pyroxasulfone applied PRE injured SRM bean $6 \%, 4 \%, 5 \%$ and $4 \%$ visible injury, respectively (Table 2). The injury was generally greater at the $2 \mathrm{X}$ rate compared to the $1 \mathrm{X}$ rate for herbicides evaluated. Pethoxamid, dimethenamid- $P$, and pyroxasulfone applied PRE at the $2 \mathrm{X}$ rates reduced SRM bean dry weight $\mathrm{m}^{-1}$ of row $26 \%, 28 \%$ and $28 \%$ and bean height $7 \%, 7 \%$ and $7 \%$, respectively (Table 3 and Table 4). There was no decrease in SRM bean dry weight $\mathrm{m}^{-1}$ of row and plant height with pethoxamid, dimethenamid- $P$ and pyroxasulfone applied PRE at the $1 \mathrm{X}$ rate or with $S$-metolachlor at the $1 \mathrm{X}$ or $2 \mathrm{X}$ rates (Table 3 and Table 4 ). In other studies, Group 15 herbicides such as $S$-metolachlor, dimethenamid- $P$ and pyroxasulfone have been shown to cause 0 to 7\% visual injury in SRM bean [9] [17] [18] [19]. Soltani et al. [13] also reported $4 \%$ to $8 \%$ injury with no adverse effect on dry weight and seed yield with pethoxamid applied PRE in SRM bean.

\subsection{White Bean}

At $4 \mathrm{WAE}$, pethoxamid, $S$-metolachlor, dimethenamid- $P$, and pyroxasulfone 
applied PRE caused 4 to 9,2 to 6,3 to 8 and $3 \%$ to $9 \%$ visible injury in white bean, respectively (Table 2 ). Pethoxamid, $S$-metolachlor, dimethenamid- $P$, and pyroxasulfone applied PRE reduced white bean dry weight $\mathrm{m}^{-1}$ of row as much as $50 \%, 37 \%, 47 \%$ and $43 \%$ and bean height as much as $16 \%, 10 \%, 16 \%$ and $15 \%$, respectively (Table 3 and Table 4). White bean dry weight and height were generally reduced more at the $2 \mathrm{X}$ rate compared to the $1 \mathrm{X}$ rate with the Group 15 herbicides evaluated, but the difference was not always statistically significant at $\mathrm{P}<0.05$. In other studies, minimal injury was reported with $S$-metolachlor applied PRE in white bean (Soltani et al. 2004). In contrast, Poling et al. [20] found significant early season visible injury with $S$-metolachlor and dimethenamid- $P$ applied PRE at 1300 and $2800 \mathrm{~g}$ ai ha $\mathrm{h}^{-1}$ in white bean, but seed yield was not affected. Taziar et al. [17] found only $3 \%$ and $10 \%$ visible injury with no yield reduction white bean with pyroxasulfone PRE at 100 and $200 \mathrm{~g}$ ai ha ${ }^{-1}$, respectively.

\subsection{Dry Bean Market Class}

At 1, 2 and 4 WAE, the Group 15 herbicides evaluated caused the greatest injury in adzuki bean, intermediate injury in white bean and least injury in SRM and kidney bean (Table 1). White bean was more sensitive to pethoxamid and dimethenamid- $P$ applied PRE than kidney bean. In contrast, adzuki bean was more sensitive to pyroxasulfone applied PRE than kidney bean (Table 2). White and SRM bean had higher yield than adzuki and kidney bean (Table 1).

\section{Conclusion}

The Group 15 herbicides evaluated caused more injury in adzuki bean compared to kidney, SRM, and white beans. This is consistent with other findings that have shown variation in sensitivity of dry bean cultivars to herbicides including Group 15 herbicides [9] [10]. The variation has been attributed to the differences in the origin and genetic composition of dry bean cultivars [6] [7] [8]. Among the Group 15 herbicides evaluated, generally, kidney and SRM bean are most tolerant, white bean is intermediate, and adzuki bean is most sensitive to Group 15 herbicides applied preemergence.

\section{References}

[1] Soltani, N., Dille, J.A., Burke, I.C., Everman, W.J., VanGessel, M.J., Davis, V.M. and Sikkema, P.H. (2018) Potential Yield Loss in Dry Bean Crops Due to Weeds in the United States and Canada. Weed Technology, 32, 342-346.

https://doi.org/10.1017/wet.2017.116

[2] Böger, P., Matthes, B. and Schmalfuß, J. (2000) Towards the Primary Target of Chloroacetamides-New Findings Pave the Way. Pest Management Science, 56, 497-508. https://doi.org/10.1002/(SICI)1526-4998(200006)56:6<497::AID-PS169>3.0.CO;2-W

[3] Trenkamp, S., Martin, W. and Teitjen, K. (2004) Specific and Differential Inhibition of Very-Long-Chain Fatty Acid Elongases from Arabidopsis thaliana by Different 
Herbicides. Proceedings of the National Academy of Sciences, 101, 11903-11908. https://doi.org/10.1073/pnas.0404600101

[4] Tanetani, Y., Kaku, K., Kawai, K., Fujioka, T. and Shimizu, T. (2009) Action Mechanism of a Novel Herbicide, Pyroxasulfone. Pesticide Biochemistry and Physiology, 95, 47-55. https://doi.org/10.1016/j.pestbp.2009.06.003

[5] Shaner, D.L. (2014) Herbicide Handbook. 10th Edition, Weed Science Society of America, Champaign, IL. 513 p.

[6] Singh, S.P., Gepts, P.and Debouck, D.G. (1991) Races of Common Bean (Phaseolus vulgaris, Fabaceae. Economic Botany, 45, 379-396.

https://doi.org/10.1007/BF02887079

[7] Singh, S.P., Gutierrez, J.A., Molina, A., Urrea, C. and Gepts, P. (1991) Genetic Diversity in Cultivated Common Bean: II. Marker-Based Analysis of Morphological and Agronomic Traits. Crop Science, 31, 23-29. https://doi.org/10.2135/cropsci1991.0011183X003100010005x

[8] Singh, S.P., Nodari, R. and Gepts, P. (1991) Genetic Diversity in Cultivated Common Bean: I. Allozymes. Crop Science, 31, 19-23. https://doi.org/10.2135/cropsci1991.0011183X003100010004x

[9] Soltani, N., Shropshire, C., Cowan, T. and Sikkema, P.H. (2004) White Bean Sensitivity to Preemergence Herbicides. Weed Technology, 18, 675-679. https://doi.org/10.1614/WT-03-130R

[10] Soltani, N., Shropshire, C., Robinson, D.E. and Sikkema, P.H. (2005) Sensitivity of Adzuki Bean (Vigna angularis) to Preplant-Incorporated Herbicides. Weed Technology, 19, 897-901. https://doi.org/10.1614/WT-05-005R1.1

[11] Stroup, W.W. (2012) Generalized Linear Mixed Models: Modern Concepts, Methods and Applications. CRC Press, Taylor \& Francis Group, Boca Raton, Florida.

[12] Rothery, P. (1988) A Cautionary Note on Data Transformation: Bias in Back-Transformed Means. Bird Study, 35, 219-221. https://doi.org/10.1080/00063658809476992

[13] Soltani, N., Nurse, R.E. and Sikkema, P.H. (2018) Sensitivity of Adzuki, Kidney, Small red Mexican, and White Beans to Pethoxamid. Canadian Journal of Plant Science, 98, 141-146.

[14] Powell, G., Sprague, C.L. and Renner, K.A. (2004) Adzuki Bean: Weed Control and Production Issues. North Central Weed Science Proceedings, 59, 32.

[15] Stewart, C.L., Nurse, R.E., Gillard, C. and Sikkema, P.H. (2010) Tolerance of Adzuki Bean to Preplant-Incorporated, Pre-Emergence, and Post-Emergence Herbicides in Ontario, Canada. Weed Biology and Management, 10, 40-47. https://doi.org/10.1111/j.1445-6664.2010.00365.x

[16] Soltani, N., Nurse, R.E., Shropshire, C. and Sikkema, P.H. (2015) Tolerance of Adzuki Bean to Pre-Emergence Herbicides. Canadian Journal of Plant Science, 95, 959-963. https://doi.org/10.4141/cjps-2015-064

[17] Taziar, A.N., Soltani, N., Shropshire, C., Robinson, D.E., Long, M., Gillard, C.L. and Sikkema, P.H. (2016) Response of Four Dry Bean Market Classes to Pre-Emergence Applications of Pyroxasulfone, Sulfentrazone and Pyroxasulfone Plus Sulfentrazone. American Journal of Plant Sciences, 7, 1217-1225.

https://doi.org/10.4236/ajps.2016.78117

[18] Sikkema, P., Soltani, N., Shropshire, C. and Cowan, T. (2004) Sensitivity of Kidney Beans (Phaseolus vulgaris) to Soil Applications of S-Metolachlor and Imazethapyr. Canadian Journal of Plant Science, 84, 405-407. https://doi.org/10.4141/P03-069 
[19] Soltani, N., Nurse, R.E., Robinson, D.E. and Sikkema, P.H. (2008) Response of Pinto and Small Red Mexican Beans (Phaseolus vulgaris L.) to Pre-Plant Incorporated Herbicides. Weed Biology and Management, 8, 25-30. https://doi.org/10.1111/j.1445-6664.2007.00270.x

[20] Poling, K.W., Renner, K.A. and Penner, D. (2009) Dry Edible Bean Class and Cultivar Response to Dimethenamid and Metolachlor. Weed Technology, 23, 73-80. https://doi.org/10.1614/WT-07-092.1 